\title{
Solvation enthalpies of the electron in polar and non-polar solvents: Theoretical study
}

\author{
Peter Škorňa, Ján Rimarčík, Erik Klein \\ Institute of Physical Chemistry and Chemical Physics, Slovak University of Technology in Bratislava, \\ Radlinského 9, SK-812 37 Bratislava, Slovakia \\ peter.skorna@stuba.sk
}

\begin{abstract}
Although the electron transfer is a part of many important processes in biosystems that occur in the solution-phase, there is still no systematic theoretical study of the electron solvation enthalpies. The solvation enthalpies of the electron in different solvents of various polarities: benzene, toluene, acetone, methanol, ethanol, DMSO and water, are investigated. All calculations were performed by B3LYP, BHLYP and PBE approaches with aug-cc-pVDZ, aug-cc-pVTZ and aug-cc-pVQZ basis sets, using the Integral Equation Formalism Polarized Continuum Model (IEF-PCM). The calculations show that the B3LYP and PBE functionals provide similar results. With the exception of benzene, toluene and DMSO, the differences in values for all solvents are lower than $6 \mathrm{~kJ} \mathrm{~mol}^{-1}$. The BHLYP solvation enthalpies are higher by $20-25 \mathrm{~kJ} \mathrm{~mol}^{-1}$ than the B3LYP ones.
\end{abstract}

Keywords: electron solvation enthalpy, solvent, DFT, IEF-PCM

\section{Introduction}

Oxidation including electron transfer is an important part of the aerobic life. For example, in mitochondria, water is formed by the reaction

$$
4 \mathrm{H}^{+}+4 \mathrm{e}^{-}+\mathrm{O}_{2} \rightarrow 2 \mathrm{H}_{2} \mathrm{O}
$$

during cell respiration. Two-step mechanisms of the primary antioxidants action also include electron transfer from the antioxidant to a scavenged free radical. In general, electron transfer represents a key elementary step in processes involving molecules, polymers, ions, electrochemical and biological systems. For the thermodynamic study of these reactions in the solution-phase, solvation enthalpy of the electron plays the crucial role. However, there is still the lack of experimental data. Although some theoretical values of electron solvation enthalpies are available, a systematic study is still missing.

The main aim of this paper is to compute the electron solvation enthalpies in commonly used solvents of various polarities and to compare them with available experimental as well as theoretical data.

The solvated electron has long been known as a metastable species in alkali metal solutions in ammonia, aliphatic amines and ethers. Its transient existence in water has been demonstrated by pulse radiolysis studies (Jortner and Noyes 1966). Available published hydration enthalpies of the electron are $\Delta H_{\text {hydr }}\left(\mathrm{e}^{-}\right)=-153.1 \mathrm{~kJ} \mathrm{~mol}^{-1}$ (Jortner and Noyes 1966) and $\Delta H_{\text {hydr }}\left(\mathrm{e}^{-}\right)=-129.3 \mathrm{~kJ} \mathrm{~mol}^{-1}$ (Donald et al. 2010). These data have been obtained as the enthalpy changes in the process

$$
\text { solvent }(l)+\mathrm{e}^{-}(\text {solv }) \rightarrow \text { solvent }^{-}(\text {solv })
$$

where the electron was "attached" to one molecule of the solvent placed in the cavity of the same solvent. The calculated gas-phase enthalpy of electron is $3.145 \mathrm{~kJ} \mathrm{~mol}^{-1}$ (Bartmess 1994).

\section{Computational methods}

All calculations were carried out using the Gaussian 03 program package (Frisch et al. 2003). The geometries of each compound or ionic structure were optimized using density functional theory (DFT) using B3LYP, BHLYP and PBE (PBE exchange functional and PBE correlation functional) functionals without any constraints (energy cut-off of $10^{-5} \mathrm{~kJ} \mathrm{~mol}^{-1}$, final RMS energy gradient under $\left.10^{-2} \mathrm{~kJ} \mathrm{~mol}^{-1} \AA-1\right)$. Dunning's correlation-consistent augmented basis sets (aug-cc-pVDZ, aug-cc-pVTZ and aug-cc-pVQZ) were applied (Dunning 1989). The optimized structures were confirmed to be real minima by vibrational analysis (no imaginary frequency). Solvent effect contributions to the total enthalpies were described by Integral Equation Formalism Polarized Continuum Model (IEF-PCM) (Cances et al. 1997). IEF-PCM calculations were carried out using default settings of Gaussian 03. In this paper, we have studied electron solvation enthalpies in seven solvents: benzene $\left(\mathrm{C}_{6} \mathrm{H}_{6}\right)$, toluene $\left(\mathrm{CH}_{3} \mathrm{C}_{6} \mathrm{H}_{5}\right)$, acetone $\left(\mathrm{CH}_{3} \mathrm{COCH}_{3}\right)$, ethanol $\left(\mathrm{CH}_{3}\right.$ $\left.\mathrm{CH}_{2} \mathrm{OH}\right)$, methanol $\left(\mathrm{CH}_{3} \mathrm{OH}\right)$, dimethylsulfoxide $\left(\mathrm{CH}_{3} \mathrm{SOCH}_{3}\right)$ and water $\left(\mathrm{H}_{2} \mathrm{O}\right)$. The total enthalpies of each molecule or ionic structure $H(\mathrm{X})$, at the 
temperature $T=298.15 \mathrm{~K}$, are estimated from the equation

$$
H(X)=E_{0}+\mathrm{ZPE}+\Delta H_{\text {trans }}+\Delta H_{\mathrm{rot}}+\Delta H_{\mathrm{vib}}+R T
$$

where $E_{0}$ is the total electronic energy, ZPE represents zero-point energy, $\Delta H_{\text {trans }}, \Delta H_{\text {rot }}, \Delta H_{\text {vib }}$ are the translation, rotation and vibration contributions to the enthalpy, respectively, and the $R T$ term ( $R$ being the universal gas constant) is added to convert the energy to the enthalpy (Atkins 1998).

\section{Results and Discussion}

The $\mathrm{e}^{-}$solvation enthalpies in studied solvents determined using IEF-PCM DFT calculations are summarized in the Table 1. B3LYP calculations of the solvation enthalpies of the electron in benzene (Table 1) are in the range from $-7 \mathrm{~kJ} \mathrm{~mol}^{-1}$ (for augcc-pVTZ basis set) to $-17 \mathrm{~kJ} \mathrm{~mol}^{-1}$ (aug-cc-pVDZ). In the Table 1 we can see that aug-cc-pVTZ basis set gives approximately the same results in comparison with aug-cc-pVQZ. Aug-cc-pVTZ basis set calculations of benzene are similar to published values of Rimarčík et al. (2010). Solvation enthalpies of electron reported by Markovič et al. (2013) are lower by ca 3-13 kJ mol-1 (B3LYP-D2 functional) and by ca $1-11 \mathrm{~kJ} \mathrm{~mol}^{-1}$ (M05-2X functional) in comparison with the B3LYP ones. BHLYP calculations for benzene are in the range from 5 to $-1 \mathrm{~kJ} \mathrm{~mol}^{-1}$ and $\mathrm{PBE}$ in the range from -30 to $-34 \mathrm{~kJ} \mathrm{~mol}^{-1}$ (see Table 1). In comparison with B3LYP, BHLYP values are higher by $20-22 \mathrm{~kJ} \mathrm{~mol}^{-1}$ and $\mathrm{PBE}$ results are lower by ca $20-25 \mathrm{~kJ} \mathrm{~mol}^{-1}$.

Toluene B3LYP values are in the range from $-23 \mathrm{~kJ} \mathrm{~mol}{ }^{-1}$ to $-27 \mathrm{~kJ} \mathrm{~mol}^{-1}$. In comparison with Rimarčík (2010), these results are lower by $10-14 \mathrm{~kJ} \mathrm{~mol}^{-1}$. PBE calculations are lower than the B3LYP ones by ca $10 \mathrm{~kJ} \mathrm{~mol}^{-1}$ (see Table 1). BHLYP solvation enthalpies have values from -1 (aug-ccpVDZ) to $-7 \mathrm{~kJ} \mathrm{~mol}^{-1}$ (aug-cc-pVTZ). In the case of BHLYP aug-cc-pVQZ calculations convergence problems appeared during the optimization of anions geometries.

Solvation enthalpies of the electron in acetone calculated with B3LYP and PBE functionals are very similar. The differences are lower than $6 \mathrm{~kJ} \mathrm{~mol}^{-1}$ (see Tables 1). In comparison with available published data, these values are lower by $25 \mathrm{~kJ} \mathrm{~mol}^{-1}$ (Rimarčík et al., 2010) and by 10-25 kJ mol-1 (Markovič et al., 2013). BHLYP solvation enthalpies are higher by

Tab. 1. Solvation enthalpies (in $\mathrm{kJ} \mathrm{mol}^{-1}$ ) of electron, $\Delta H\left(\mathrm{e}^{-}\right)$, in studied solvents.

\begin{tabular}{lccccccccc}
\hline \multirow{2}{*}{ Solvent } & \multicolumn{3}{c}{ Aug-cc-pVDZ } & \multicolumn{3}{c}{ Aug-cc-pVTZ } & \multicolumn{3}{c}{ Aug-cc-pVQZ } \\
\cline { 2 - 9 } & B3LYP & BHLYP & PBE & B3LYP & BHLYP & PBE & B3LYP & BHLYP & PBE \\
\hline Benzene & -17 & 5 & -30 & -7 & -1 & -32 & -8 & $*$ & -34 \\
Toluene & -23 & -1 & -33 & -25 & -7 & -35 & -27 & $*$ & -39 \\
Acetone & -145 & -120 & -149 & -141 & -116 & -147 & -141 & -115 & -147 \\
Ethanol & -90 & -69 & -96 & -91 & -70 & -97 & -91 & -71 & -98 \\
Methanol & -100 & -79 & -105 & -101 & -81 & -106 & -102 & -82 & -107 \\
DMSO & -90 & -76 & -103 & -96 & -79 & -103 & -96 & -79 & -103 \\
Water & -119 & -97 & -120 & -118 & -97 & -120 & -118 & -97 & -120 \\
\hline
\end{tabular}

*Convergence problems.

Tab. 2. Theoretical solvation enthalpies (in $\mathrm{kJ} \mathrm{mol}^{-1}$ ) of electron, $\Delta H\left(\mathrm{e}^{-}\right)$in studied solvents and their relative permitivities, $\varepsilon_{\mathrm{r}}$. All approaches used 6-311++ $\mathrm{G}^{* *}$ basis set.

\begin{tabular}{lcccc}
\hline solvent & $\varepsilon_{\mathrm{r}}{ }^{\mathrm{a}}$ & B3LYP $^{\mathrm{b}}$ & B3LYP-D2 $^{\mathrm{c}}$ & M05-2X $^{\mathrm{d}}$ \\
\hline Benzene & 2.271 & -7 & -20 & -18 \\
Toluene & 2.374 & -13 & - & - \\
Acetone & 20.493 & -119 & -133 & -120 \\
Ethanol & 24.852 & -76 & -74 & -44 \\
Methanol & 32.613 & -86 & -80 & -49 \\
DMSO & 46.826 & -84 & -56 & -29 \\
Water & 78.355 & -105 & -101 & -66 \\
\hline
\end{tabular}

${ }^{\mathrm{a}}$ From the Ref. (Wilhelm and Battino 1973), and references therein.

${ }^{\mathrm{b}}$ From the Ref. (Rimarčík et al. 2010).

'From the Ref. (Markovič et al. 2013).

${ }^{\mathrm{d}}$ From the Ref. (Markovič et al. 2013). 
$25-30 \mathrm{~kJ} \mathrm{~mol}^{-1}$ with the values being from -115 to $-120 \mathrm{~kJ} \mathrm{~mol}^{-1}$.

Similarly as in the case of acetone, calculated solvation enthalpies of the electron in ethanol found with B3LYP and PBE functionals are very close. B3LYP calculations of ethanol are in a narrow range from -90 to $-91 \mathrm{~kJ} \mathrm{~mol}^{-1}$. These values are considerably lower in comparison with Rimarčík et al. (2010) and Markovič et al. (2013) by $15-45 \mathrm{~kJ} \mathrm{~mol}^{-1}$ (Table 2). BHLYP results are also in a narrow range from -69 to $-71 \mathrm{~kJ} \mathrm{~mol}^{-1}$. These values are higher by ca $20-25 \mathrm{~kJ} \mathrm{~mol}^{-1}$ in comparison with B3LYP and PBE calculations.

B3LYP solvation enthalpies of the electron in methanol reached values in a narrow range (from -100 to -102 kJ mol ${ }^{-1}$ ). Rimarčík et al. (2010) published B3LYP/6-311++ $\mathrm{G}^{* *}$ value of $-86 \mathrm{~kJ} \mathrm{~mol}^{-1}$. In Markovic et al. (2013), the electron solvation enthalpy reached values of $-80 \mathrm{~kJ} \mathrm{~mol}^{-1}$ (B3LYP-D2 functional) and $-49 \mathrm{~kJ} \mathrm{~mol}^{-1}$ (M05-2X functional). BHLYP calculations are lower by ca $20 \mathrm{~kJ} \mathrm{~mol}^{-1}$ with respect to the B3LYP ones. On the other hand, PBE solvation enthalpies are in a good agreement with B3LYP values, they are in a narrow range from -105 to $-107 \mathrm{~kJ} \mathrm{~mol}^{-1}$.

B3LYP calculations for DMSO are in the range from -90 to $-96 \mathrm{~kJ} \mathrm{~mol}^{-1}$. It is by about $6-12 \mathrm{~kJ} \mathrm{~mol}^{-1}$ lower than the published data (Rimarčík et al., 2010). Markovič et al. (2013) data are higher, $-56 \mathrm{~kJ} \mathrm{~mol}^{-1}$ for B3LYP-D2 functional and $-29 \mathrm{~kJ} \mathrm{~mol}^{-1}$ for M052X functional. BHLYP values are by ca $20 \mathrm{~kJ} \mathrm{~mol}^{-1}$ higher in comparison with B3LYP, they are in a narrow range from -76 to $-79 \mathrm{~kJ} \mathrm{~mol}^{-1}$. PBE calculations give the value of $-103 \mathrm{~kJ} \mathrm{~mol}^{-1}$.

B3LYP and PBE solvation enthalpies of the electron in water $\left(\mathrm{ca}-120 \mathrm{~kJ} \mathrm{~mol}^{-1}\right)$ are in a good agreement with experimental data of Donald et al. (2010) (see Table 1). Differences are lower than $10 \mathrm{~kJ} \mathrm{~mol}^{-1}$. Published calculations are lower by $15 \mathrm{~kJ} \mathrm{~mol}^{-1}$ (Rimarčík et al., 2010) and by $20-55 \mathrm{~kJ} \mathrm{~mol}^{-1}$ (Markovič et al., 2013). BHLYP calculations provide the value of $-97 \mathrm{~kJ} \mathrm{~mol}^{-1}$.

As we can see in the Table 1, the solvation enthalpies obtained using various functionals exhibit the same trends. For B3LYP and PBE functionals, with the exception of benzene, toluene and DMSO, the differences of values for all remaining solvents are lower than $6 \mathrm{~kJ} \mathrm{~mol}^{-1}$ (Table 1). All BHLYP values are higher by $20-25 \mathrm{~kJ} \mathrm{~mol}^{-1}$ in comparison with the B3LYP ones. Interesting results provide BHLYP calculations for benzene predicting positive solvation enthalpies, in the range from 5 to $-1 \mathrm{~kJ} \mathrm{~mol}^{-1}$ (Table 1).

\section{Conclusion}

In this paper, quantum chemical calculations of electron solvation enthalpies were presented. Sol- vents of various polarities were subjects of IEF-PCM DFT calculations. B3LYP and PBE functionals provide similar results. With the exception of benzene, toluene and DMSO, the differences of values for all solvents are lower than $6 \mathrm{~kJ} \mathrm{~mol}^{-1}$. Obtained electron solvation enthalpies are in some cases significantly different from previously published data. The PBE solvation enthalpy of the electron in water is in a good agreement with experimental data of Donald et al. (2010). The calculated electron solvation enthalpies, $\Delta_{\text {solv }} H\left(\mathrm{e}^{-}\right)$, can be utilized in the evaluation of reaction enthalpies of various electron transfer processes in a solution phase.

\section{Acknowledgement}

This work was supported by the Slovak Grant Agency VEGA (contracts Nos.1/0735/13 and 1/0072/11). We are grateful to the HPC center at the Slovak University of Technology in Bratislava, which is a part of the Slovak Infrastructure of High Performance Computing (SIVVP project, ITMS code 26230120002, funded by the European region development funds), for the computational time and resources made available.

\section{References}

Atkins PW (1998) Physical chemistry, 6th ed., Oxford University Press, Oxford.

Bartmess JE (1994) J. Phys. Chem. 98: 6420-6424.

Cances E, Mennucci B, Tomasi J (1997) J. Chem. Phys. 107: 3032-3041.

Donald AW, Demireva M, Leib DR, Aiken J, Williams RE (2010) J. Am. Chem. Soc. 132: 4633-4640.

Dunning TH Jr. (1989) J. Chem. Phys. 90: 1007-1023.

Frisch MJ, Trucks GW, Schlegel HB Scuseria GE, Robb MA, Cheeseman JR, Montgomery JA, Jr., Vreven T, Kudin KN, Burant JC, Millam JM, Iyengar SS, Tomasi J, Barone V, Mennucci B, Cosi M, Scalmani G, Rega N, Petersson GA, Nakatsuji H, Hada M, Ehara M, Toyota K, Fukuda R, Hasegava J, Ishida M, Nakajima T, Honda Y, Kitao O, Nakai H, Klene M, Li X, Knox JE, Hratchian HP, Cross JB, Adamo C, Jaramillo J, Gomperts R, Stratmann RE, Yazyev O, Austin AJ, Cammi R, Pomelli C, Ochterski JW, Ayala PY, Morokuma K, Voth GA, Salvador P, Dannenberg JJ, Zakrzewski VG, Dapprich S, Daniels AD, Strain M-C, Farkas O, Malick DK, Rabuck AD, Raghavachari K, Foresman JB, Ortiz JV, Cui Q, Baboul AG, Clifford S, Cioslowski J, Stefanov BB, Liu G, Liashenko A, Piskorz P, Komaromi I, Martin RL, Fox DJ, Keith T, Al-Laham MA, Peng CY, Nakaryakkara A, Chalacombe M, Gill PMW, Johnson B, Chen W, Wong MW, Gonzales C, Pople JA (2003) GAUSSIAN 03, Revision A.1, Gaussian, Inc., Pittsburgh, PA.

Jortner J, Noyes MR (1966) J. Phys. Chem. 70: 770-774.

Markovič Z, Milenkovič D, Dorovič J, Jeremič S (2013) J. Serb. Soc. Comp. Mech. 7: 1-9.

Rimarčík J, Lukeš V, Klein E, Ilčin M (2010) J. Mol. Struc: THEOCHEM 952: 25-30.

Wilhelm E, Battino R (1973) Chem. Rev. 73: 1-9. 